\title{
LIFE CYCLE ASSESSMENT AND THE ENVIRONMENTAL CERTIFICATION SYSTEMS OF BUILDINGS
}

\author{
Avaliação de Ciclo de Vida e Sistemas de Certificação \\ Ambiental de Edificações
}

\author{
Cristiane Bueno', João Adriano Rossignolo², Aldo Roberto Ometto ${ }^{3}$
}

\begin{abstract}
The life cycle assessment (LCA) is an important methodology for the assessment of building components and systems and should be used within the building environmental performance certification systems. The present paper reports on the state of the art of LCA as a tool for the assessment of building components and analyzes its application in the environmental certification systems of buildings. The analysis of four of the main buildings rating systems currently used has revealed that, among them, Green Globes is the only one which uses the LCA methodology to evaluate the environmental performance of building components. The other systems use the assessment of building components by the recognition of product attributes such as cost, durability, renewability and recycled content. The weakness of the attributes approach lies in the fact that these attributes are treated in isolation and lack the whole concept of impact.
\end{abstract}

KEYWORDS Environmental assessment of buildings, life cycle assessment, building materials, environmental certification systems.

RESUMO A Avaliação de Ciclo de Vida (ACV) é uma importante metodologia a ser utilizada
na avaliação ambiental de sistemas e componentes construtivos, cuja aplicação pode ser de
grande valia nos sistemas de certificação ambental de edifícios. O presente artigo investiga
o estado da arte da metodologia de ACV como ferramenta de avaliação de materiais e
componentes construtivos e analisa sua aplicação em sistemas de certificação ambiental de
edifícios. A análise revelou que, dentre os quatro sistemas mais importantes e amplamente
empregados da atualidade, o Green Globes é o único que se utiliza da metodologia de ACV para
avaliar o desempenho ambiental de materiais e componentes contrutivos. Os demais sistemas
de certificação ambiental de edifícios fazem uso da abordagem de reconhecimento de
atributos, a qual avalia características isoladas de tais produtos, tais como custo, durabilidade,
renovabilidade, conteúdo reciclado, etc. A fragilidade da abordagem de avaliação por atributos
se encontra no fato de que tais atributos são tratados isoladamente, perdendo-se a visão
holística e, consequentemente, o conceito global de impacto.

PALAVRAS-CHAVE Avaliação ambiental de edifícios, avaliação de ciclo de vida, materiais de construção, sistemas de certificação ambiental.
How to cite this article:

BUENO, C.; ROSSIGNOLO, J. A.; OMETTO, A. R. Life cycle assessment and the environmental certification systems of buildings. Gestão e Tecnologia de Projetos, São Paulo, v. 8, n. 1, p. 7-18, jan.-jun. 2013. http://dx.doi.org/10.4237/gtp. v8i1.255
Fonte de financiamento: CAPES (bolsa de doutorado) Conflito de interesse: Declaram não haver

Submetido em: 28.11.2012 Revisado em: 07.05.2013 Aceito em: 12.06.2013 


\section{INTRODUCTION}

The need to meet the principles of sustainable development, as well as new economic models has changed expectations regarding the durability of buildings and introduced the lifetime planning of the process (HANS et al., 2008).

The use of energy, water and land by the industry of building materials, building construction and operation of their services is responsible for a dominant part of the total environmental impact caused by society (ERLANDSSON; BORG, 2003).

Slight changes in the various stages of the construction process can promote important changes in environmental efficiency and reduce operating expenses. In this increasingly competitive market, subject to command control (laws and regulations) and continuous improvement instruments, the choice of building components is an important field of environmentally responsible engineering (SOARES; SOUZA; PEREIRA, 2006). Moreover, in the search for improvements in the environmental performance of buildings, additional materials and components are often used, which results in an increased embodied energy, regarding the production and transportation of such additional items (VERBEECK; HENS, 2010).

This preoccupation regarding sustainable development, especially in its environmental dimension, has resulted in dozens of Assessment Methods of Building Environmental Performance in different countries, with several criteria and methods of assessment and certification. Therefore the efficiency of the application of such performance evaluation tools is directly related to the context to which they are applied (PATRICIO; GOUVINHAS, 2004).

In order to assess the overall impact of reduction measures of resource consumption during the lifetime of a building, carrying out a Life Cycle Assessment (LCA) has shown to be a valuable tool (VERBEECK; HENS, 2010). An LCA study consists in analyzing the environmental impacts of a product or activity from an inventory of inputs and outputs (raw materials, energy, products, subproducts and waste) of the system (SOARES; SOUZA; PEREIRA, 2006). The system boundaries must consider the steps of the extraction of raw materials, transportation, manufacture, use and disposal, i.e. the complete life cycle. This procedure enables a scientific assessment of the situation and facilitates the recognition of possible changes associated with different stages of the life cycle, which may result in improvements in the product's environmental profile.

From an environmental perspective, LCA provides as complete inventories as possible of the mass and energy flows to each system and allows the comparison of these balances in the form of environmental impacts (SOARES; SOUZA; PEREIRA, 2006). The life cycle of a building includes the production of building materials, construction, operation, maintenance, disassembly and waste management (GUSTAVSSON; JOELSSON, 2010). Thus the LCA metodology may be an important part of the environmental assessment methods of buildings.

Previous studies, such as those by Erlandsson and Borg (2003), Haapio and Viitaniemi (2008) and Nibel et al. (2005) have allowed the LCA methodology for buildings to be reviewed, however there are still some lacks regarding environmental indicators, complexity of LCA disclosure for users, simplifications and adaptations for different purposes (BRIBIÁN; USÓN; SCARPELLINI, 2009).

Given the current scenario of the assessment of environmental performance and lifecycle of building systems, this paper reports on a survey of the existing tools currently used for this purpose. 


\section{GOALS AND JUSTIFICATION}

The purpose of this study is to build a summary table and a comprehensive discussion on the methods used by major certification systems for the environmental assessment of building components through data collected from the literature review.

The certification systems chosen are GBTool (COLE; LARSSON, 2002), Green Globes (SKOPEK; BRYAN, 2002), AQUA (FUNDAÇÃO..., 2007) and LEED (UNITED..., 2009).

GBTool (COLE; LARSSON, 2002) stands out as the first certification that seeks flexibility and score balance in order to be adaptable to different regional characteristics.

In its specificity, the Green Globes (SKOPEK; BRYAN, 2002) is representative for this research because it is originally a tool for online selfassessment. The rating system is maintained by the Green Building Initiative and BOMA Canada and is based in the English BREEAM certification system (BUILDING..., 2011), one of the most outstanding rating systems worldwide.

AQUA certification (FUNDAÇÃO..., 2007) is the first initiative of a rating system adaptation to the specific Brazilian context. For this reason the analysis of regional characteristics of its assessment criteria is an interesting focus for this research. Such certification system was adapted from the French Demarche Haute Qualité Environnementale (CERTIVÉA, 2012), which is one of the most applied and important building performance rating systems today.

Finally, the LEED (UNITED..., 2009) certification system is the main current initiative to assess the environmental performance of buildings. It has remained the primary system used due to its high international marketing recognition. Another important nuance of LEED certification system is that it provides different rating systems for specific situations and buildings, such as homes, new constructions, core and shell, existing buildings, and so on. In our study we considered the LEED New Construction Rating System for analysis.

\section{METHODS}

The basis of the discussion proposed in this paper is a literature review on the applications of the LCA methodology in civil construction, as well as parameters used by the environmental certification systems for the assessment of building components.

According to the objective of the paper, the methodology procedures are divided into three main stages:

- Survey of the state of the art of the use of LCA in civil construction;

- Investigation and development of a summary table of the building components assessment methodologies used by the main environmental performance certification systems;

- Conclusions on the strengths and weaknesses of the assessment methods applied by each of the analyzed rating systems.

\section{APPLICABILITY OF THE LCA TO BUILDING SYSTEMS}

Among the methods and tools for the environmental assessment of buildings, some are specifically designed for the selection of building materials and components and others may be used for it, although they were not originally created for this purpose. A wide range of environmental concerns has led to the consideration of waste emissions and depletion of natural resources, which should be incorporated into a more comprehensive evaluation framework. In this scenario, LCA has emerged as a recognized 
method and also the basis for the development of several assessment tools. On the other hand, the complexity of construction products - including materials, systems, subsystems, and the endless possibilities for combining them into a building - has generated more multifaceted products than the final goods usually evaluated by LCA so far (JOHN; OLIVEIRA; AGOPYAN, 2006).

According to ABNT (ASSOCIAÇÃO..., 2009), Life Cycle Assessment (LCA) is the compilation and evaluation of inputs, outputs and potential environmental impacts of a product system throughout its life cycle, considering it holistically.

To minimize the obstacles in the application of conventional LCA methodology to the construction industry, Chevalier and Le Teno (1996) proposed some special requirements for the LCA of building systems:

- Special rules to establish system boundaries must be set to force separability;

- Specific processes for building systems must be modeled;

- The assumption of stability over time should be forced or canceled;

- The assumption of accuracy must be canceled;

- The quality of data and relations between them should be documented;

- The list of impact stressors must be open to user-defined criteria, according to a well documented negotiation process;

- Assistance should be provided to users for the management of results;

- A computer program must be used to assist the process.

Despite the limitations presented in this paper, the LCA has shown to be the most complete and reliable tool for the selection of building materials based on environmental performance quantitative criteria. With the current dissemination of research on this subject, the trend is that databases on construction products will become more abundant, easing their implementation and reducing costs.

\section{LCA AND ASSESSMENT OF BUILDING COMPONENTS IN THE ENVIRONMENTAL CERTIFICATION SYSTEMS}

According to (BUENO et al., 2011), in order to the certification systems of building environmental performance to be compared, they must be standardized. In the particular case of the rating systems analyzed by this paper, they must be organized by the following evaluation categories: Design Process, Connections, Implantation, Resource Consumption, Emissions, Comfort and Environmental Quality, Services, Economic Aspects and Operation Planning.

Within these categories and for each certification system, there are a number of credits, which develop the building assessment according to a range of topics. Therefore the credits concerning the assessment of building components are concentrated in the categories related to resource consumption, environmental quality and emissions, as shown in Table 1.

As we can conclude by Table 1, the certification systems allocate credits related to building materials assessment differently.

In the LEED certification system those credits are placed in the categories "Materials and Resources" and "Indoor Environmental Quality".

GBTool and Green Globes use a similar distribution, concentrating those items in the categories "Resources Consumption" and "Emissions" (or "Loadings").

Finally, the AQUA certification system is the only one which provides a whole category totally dedicated to the evaluation of materials and components: "Integrated choice of construction products, systems, and processes”. 
Table 1. Assessment of materials in the certification systems categories.

\begin{tabular}{|c|c|c|c|c|}
\hline \multirow{2}{*}{$\begin{array}{l}\text { Assessment } \\
\text { Categories }\end{array}$} & \multicolumn{4}{|c|}{ Categories to be compared by Certification Systems } \\
\hline & $\begin{array}{l}\text { GBTool (COLE; } \\
\text { LARSSON, 2002) }\end{array}$ & $\begin{array}{c}\text { Green Globes } \\
\text { (SKOPEK; BRYAN, } \\
\text { 2002) }\end{array}$ & $\begin{array}{c}\text { AQUA (FUNDAÇÃO..., } \\
\text { 2007) }\end{array}$ & $\begin{array}{l}\text { LEED (UNITED..., } \\
\text { 2009) }\end{array}$ \\
\hline $\begin{array}{l}\text { Design } \\
\text { Process }\end{array}$ & & $\begin{array}{l}\text { - Design } \\
\text { Management }\end{array}$ & $\begin{array}{l}\text { - Integrated choice of } \\
\text { construction products, } \\
\text { systems and processes }\end{array}$ & $\begin{array}{l}\text { - Innovation and } \\
\text { Design Process }\end{array}$ \\
\hline Connections & - Daily transport & & $\begin{array}{l}\text { - Relationship between } \\
\text { the building and its } \\
\text { surroundings }\end{array}$ & $\begin{array}{l}\text { - Location and } \\
\text { Linkages }\end{array}$ \\
\hline Implantation & & - Site & & - Sustainable Sites \\
\hline \multirow{3}{*}{$\begin{array}{l}\text { Resource } \\
\text { Consumption }\end{array}$} & - Resource & - Energy & - Energy management & - Water Efficiency \\
\hline & Consumption & - Water & - Water management & $\begin{array}{l}\text { - Energy and } \\
\text { Atmosphere }\end{array}$ \\
\hline & & - Resources & $\begin{array}{l}\text { - Integrated choice of } \\
\text { construction products, } \\
\text { systems and processes }\end{array}$ & $\begin{array}{l}\text { - Materials and } \\
\text { Resources }\end{array}$ \\
\hline Emissions & $\begin{array}{l}\text { - Loadings } \\
\text { (Environmental } \\
\text { Loads) }\end{array}$ & $\begin{array}{l}\text { - Emissions, } \\
\text { effluents and other } \\
\text { impacts }\end{array}$ & $\begin{array}{l}\text { - Management of the } \\
\text { waste from the use } \\
\text { and operation of the } \\
\text { building }\end{array}$ & $\begin{array}{l}\text { - Energy and } \\
\text { Atmosphere }\end{array}$ \\
\hline Comfort and & - Indoor & - Indoor & - Hygrothermal & - Indoor \\
\hline $\begin{array}{l}\text { Environmental } \\
\text { Quality }\end{array}$ & $\begin{array}{l}\text { Environmental } \\
\text { Quality }\end{array}$ & Environment & $\begin{array}{l}\text { Comfort } \\
\text { - Acoustic Comfort } \\
\text { - Visual Comfort } \\
\text { - Olfactory Comfort } \\
\text { - Sanitary quality of the } \\
\text { environment, air and } \\
\text { water }\end{array}$ & $\begin{array}{l}\text { Environmental } \\
\text { Quality }\end{array}$ \\
\hline Services & $\begin{array}{l}\text { - Quality of } \\
\text { Service }\end{array}$ & & & \\
\hline $\begin{array}{l}\text { Economic } \\
\text { Aspects }\end{array}$ & - Economy & & & \\
\hline $\begin{array}{l}\text { Operation } \\
\text { Planning }\end{array}$ & - Management & & $\begin{array}{l}\text { - Construction site } \\
\text { with low environmental } \\
\text { impact } \\
\text { - Maintenance - } \\
\text { Permanence of } \\
\text { environmental } \\
\text { performance }\end{array}$ & $\begin{array}{l}\text { - Awareness and } \\
\text { Education }\end{array}$ \\
\hline
\end{tabular}

Source: Bueno et al. (2011).

Regarding the assessment methodology, the recognition of product attributes such as cost, durability, renewability and recycled content currently prevail. This approach deals with such attributes single-handedly, when in fact they are often in conflict and interfering with each other (SILVA, 2007). For this reason, the attributes approach lacks a sense of the overall impact of a product. 
Tables 2, 3, 4 and 5 show the assessment methodologies used by the credits regarding building materials in the four environmental performance certification systems of buildings approached in this research, respectively: LEED 2009, AQUA, GBTool, and Green Globes.

From a holistic perspective, the following limitations were observed in the approaches presented by the certification systems:

- Use of certified materials, which are not commercially available worldwide;

- The classification and certification of building components are still a hardly feasible practice due to the scarcity of data on the origin of raw materials, processes and resources used in the product chain;

- Predominant recognition of product attributes, approach in which such attributes are treated separately, losing the holistic concept of impact as well as the interrelations between them.

Starting from the principle that there is a clear interaction between the life stages of a building, the implementation of a comprehensive methodology, such as a LCA may be useful identify the hotspots for improvements, since this method evaluates the overall impact on the environment during the building lifespan (BRIBIÁN; USÓN; SCARPELLINI, 2009).

Table 2. Methodology of building materials assessment in the LEED certification system.

\begin{tabular}{|c|c|c|}
\hline $\begin{array}{l}\text { Evaluative credits regarding } \\
\text { building components }\end{array}$ & Category & Assessment methodology \\
\hline Recycled Content & $\begin{array}{l}\text { Materials and } \\
\text { resources }\end{array}$ & $\begin{array}{l}\text { Attributes - Evaluation of the use of materials with } \\
\text { recycled content so that the sum of pre-consumer and } \\
\text { post-consumer recycled content constitute } 10-20 \% \text { of the } \\
\text { material's mass. }\end{array}$ \\
\hline Regional Materials & $\begin{array}{l}\text { Materials and } \\
\text { resources }\end{array}$ & $\begin{array}{l}\text { Attributes - Evaluation whether the distance from the } \\
\text { extraction and production sites of the material is shorter } \\
\text { than } 500 \text { miles from the construction site for at least 10- } \\
20 \% \text { of the materials used. }\end{array}$ \\
\hline Rapidly Renewable Materials & $\begin{array}{l}\text { Materials and } \\
\text { resources }\end{array}$ & $\begin{array}{l}\text { Attributes - Evaluation whether at least } 2.5 \% \text { of the } \\
\text { total cost of building materials and systems refers to } \\
\text { items whose main raw materials are rapidly renewable } \\
\text { (vegetable origin with cycles of less than } 10 \text { years). }\end{array}$ \\
\hline Certified wood & $\begin{array}{l}\text { Materials and } \\
\text { resources }\end{array}$ & $\begin{array}{l}\text { Attributes - Evaluation whether at least } 50 \% \text { of the } \\
\text { wooden systens are composed of certified materials. }\end{array}$ \\
\hline $\begin{array}{l}\text { Low-Emitting Materials- } \\
\text { adhesives and sealants }\end{array}$ & $\begin{array}{l}\text { Indoor } \\
\text { Environmental } \\
\text { Quality }\end{array}$ & $\begin{array}{l}\text { Attributes - All adhesives and sealants used in the } \\
\text { interior of the building must comply with the Volatile } \\
\text { organic compound (VOC) limits of the listed standards. }\end{array}$ \\
\hline $\begin{array}{l}\text { Low-Emitting Materials-Paints } \\
\text { and Coatings }\end{array}$ & $\begin{array}{l}\text { Indoor } \\
\text { Environmental } \\
\text { Quality }\end{array}$ & $\begin{array}{l}\text { Attributes - Paints and coatings used in the interior } \\
\text { of the building must comply with the Volatile organic } \\
\text { compound (VOC) limits of the listed standards. }\end{array}$ \\
\hline $\begin{array}{l}\text { Low-Emitting Materials- } \\
\text { flooring systems }\end{array}$ & $\begin{array}{l}\text { Indoor } \\
\text { Environmental } \\
\text { Quality }\end{array}$ & $\begin{array}{l}\text { Attributes - All flooring must comply with the Volatile } \\
\text { organic compound (VOC) limits and other rules of the } \\
\text { listed standards. }\end{array}$ \\
\hline $\begin{array}{l}\text { Low-Emitting Materials- } \\
\text { Composite wood and agrifiber } \\
\text { Products }\end{array}$ & $\begin{array}{l}\text { Indoor } \\
\text { Environmental } \\
\text { Quality }\end{array}$ & $\begin{array}{l}\text { Attributes - Composite wood, agrifiber products and } \\
\text { Laminating adhesives used in the building must contain no } \\
\text { added urea-formaldehyde resins. }\end{array}$ \\
\hline
\end{tabular}


Table 3. Methodology of building materials assessment in the AQUA certification system.

\begin{tabular}{|c|c|c|}
\hline $\begin{array}{l}\text { Evaluative credits regarding building } \\
\text { components }\end{array}$ & Category & Assessment methodology \\
\hline $\begin{array}{l}\text { Constructive choices aiming at } \\
\text { durability and adaptability of the } \\
\text { building }\end{array}$ & $\begin{array}{l}\text { Integrated choice of } \\
\text { products, systems } \\
\text { and construction } \\
\text { processes }\end{array}$ & $\begin{array}{l}\text { Attributes - Concern the lifespan of products, } \\
\text { systems and processes regarding their use in } \\
\text { the building. }\end{array}$ \\
\hline $\begin{array}{l}\text { Constructive choices aiming at the } \\
\text { ease of maintenance of the building }\end{array}$ & $\begin{array}{l}\text { Integrated choice of } \\
\text { products, systems } \\
\text { and construction } \\
\text { processes }\end{array}$ & $\begin{array}{l}\text { Attributes - Evaluation of the choice for easy- } \\
\text { maintenance products. }\end{array}$ \\
\hline $\begin{array}{l}\text { Choice of construction products } \\
\text { in order to limit the social and } \\
\text { environmental impacts of } \\
\text { construction }\end{array}$ & $\begin{array}{l}\text { Integrated choice of } \\
\text { products, systems } \\
\text { and construction } \\
\text { processes }\end{array}$ & $\begin{array}{l}\text { Attributes - Evaluation of the environmental } \\
\text { attributes of construction products regarding } \\
\text { the emission of greenhouse gases, generation } \\
\text { of waste, possibility of reuse/recycling of } \\
\text { materials, use of renewable resources and } \\
\text { depletion of natural resources. }\end{array}$ \\
\hline $\begin{array}{l}\text { Choice of construction products in } \\
\text { order to limit the impacts to human } \\
\text { health }\end{array}$ & $\begin{array}{l}\text { Integrated choice of } \\
\text { products, systems } \\
\text { and construction } \\
\text { processes }\end{array}$ & $\begin{array}{l}\text { Attributes - Evaluation of the characteristics } \\
\text { of the interior lining products in emissions of } \\
\text { pollutants harmful to human health. }\end{array}$ \\
\hline
\end{tabular}

Table 4. Methodology of building materials assessment in the GBTool certification system.

\begin{tabular}{|c|c|c|}
\hline $\begin{array}{l}\text { Evaluative credits regarding building } \\
\text { components }\end{array}$ & Category & Assessment methodology \\
\hline Net life-cycle use of primary energy & $\begin{array}{l}\text { Resource } \\
\text { Consumption }\end{array}$ & $\begin{array}{l}\text { Partial LCI - Evaluation of the energy inputs } \\
\text { over the life cycle of building materials. }\end{array}$ \\
\hline $\begin{array}{l}\text { Use of salvaged materials from off- } \\
\text { site sources }\end{array}$ & $\begin{array}{l}\text { Resource } \\
\text { Consumption }\end{array}$ & $\begin{array}{l}\text { Attributes - Evaluation of the percentage } \\
\text { of materials recovered from external } \\
\text { sources in relation to the total weight of } \\
\text { materials used in the building. }\end{array}$ \\
\hline $\begin{array}{l}\text { Recycled content of materials from } \\
\text { off-site sources }\end{array}$ & $\begin{array}{l}\text { Resource } \\
\text { Consumption }\end{array}$ & $\begin{array}{l}\text { Attributes - Evaluation of the recycled } \\
\text { content percentage in the total mass of } \\
\text { materials used. }\end{array}$ \\
\hline $\begin{array}{l}\text { Use of certified or equivalent wood } \\
\text { products }\end{array}$ & $\begin{array}{l}\text { Resource } \\
\text { Consumption }\end{array}$ & $\begin{array}{l}\text { Attributes - Evaluation of the percentage } \\
\text { of wood systems which comprise certificate } \\
\text { or equivalent materials. }\end{array}$ \\
\hline $\begin{array}{l}\text { Embodied emissions of materials } \\
\text { annualized over the life-cycle }\end{array}$ & Loadings & $\begin{array}{l}\text { Attributes - Counting of the annualized } \\
\text { greenhouse gas emissions normalized for } \\
\text { building areas: kg CO2 } \\
\text { equiv./m2 /year. Only for the production } \\
\text { process of materials }\end{array}$ \\
\hline $\begin{array}{l}\text { Emission of ozone-depleting } \\
\text { substances }\end{array}$ & Loadings & $\begin{array}{l}\text { Attributes - Annual kg CFC-11equiv. } \\
\text { normalized for area: kg CFC-11equiv. /m2/ } \\
\text { year }\end{array}$ \\
\hline $\begin{array}{l}\text { Emission of gases leading to } \\
\text { acidification from building operations }\end{array}$ & Loadings & $\begin{array}{l}\text { Attributes - Annual kg of SO2 equiv. } \\
\text { normalized for area: kg of SO2 equiv /m2/ } \\
\text { year }\end{array}$ \\
\hline $\begin{array}{l}\text { Avoidance of solid waste resulting } \\
\text { from construction processes }\end{array}$ & Loadings & $\begin{array}{l}\text { Attributes - The percentage by weight of } \\
\text { solid wastes resulting from construction of } \\
\text { the new or renovated facility on the site that } \\
\text { will not be sent to a solid waste facility. }\end{array}$ \\
\hline
\end{tabular}


Table 5. Methodology of building materials assessment in the Green Globes certification system.

\begin{tabular}{|l|l|l|}
\hline $\begin{array}{c}\text { Evaluative credits regarding building } \\
\text { components }\end{array}$ & Category & \multicolumn{1}{c|}{ Assessment methodology } \\
\hline Minimal Consumption of Resources & Resources & $\begin{array}{l}\text { Attributes - Evaluation of the use of recycled, } \\
\text { reused, locally sourced and low-maintenance } \\
\text { materials and certified wood. }\end{array}$ \\
Low Impact Systems \& Materials & Resources & $\begin{array}{l}\text { LCA - Evaluation of the use of materials with } \\
\text { low environmental impact throughout their life } \\
\text { cycle. }\end{array}$ \\
\hline
\end{tabular}

\section{DISCUSSION}

Among the credits regarding the environmental assessment of building materials in the four certification systems, most use the attributes approach, as seen in the Tables 2, 3, 4 and 5 .

In the LEED certification system, all the credits related to the issue addressed in this paper use the attributes assessment, as shown in Table 2. Such approach makes the rating system easier to use, the main reason of its high spreadability. However the attibuttes approached by the system are also higly simplistic and show no correlation.

The first, "Materials with recycled content", evaluates whether the sum of the pre-consumer and post-consumer recycled content constitutes 10-20\% of the material, and the score varies according to the achieved percentage. In the same path, in the evaluation of "Rapidly renewable materials" the objective is to use products with rapidly renewable main raw materials for at least $2.5 \%$ of the total cost of building systems. A raw material is considered rapidly renewable by the certification system when it has vegetal origin, with renovation cycles of less than 10 years.

Although the recycled content and renewable sources issues are important to environmental assessment, in these approaches they might be assessed only punctually in order to achieve the minimum score.

The credit "Regional materials" aims to assess wheter the distance from the place of extraction and production of the building materials is shorter than 500 miles from the construction site for at least $10-20 \%$ of the materials used. Similarly to the previous credit, the building can reach a better score, according to the percentage achieved. However for other materials that are not scored on this credit, there is no maximum limit of distance between production and use, and thus no holistic control of the actual impacts.

The use of certified wood in at least $50 \%$ of the wooden systems is also evaluated, in order to assure the procedence of timbers. Nevertheless the credit has no further evaluation of the type of wood, what can change several potencial impact parameters, as the freshwater consumption, for instance.

This certification system have some credits concerning the evaluation of building components which are comprised in the "Indoor Environmental Quality" category. Some of those credits, which also use the attributes approach method, account the VOC (volatile organic compounds) emissions from materials, such as adhesives and sealants, paints and coatings and flooring systems.

Likewise the last credit of this category requires that composite wood, agrifiber products and laminating adhesives used in the building must contain no added urea-formaldehyde resins. Such credit also uses the attibutes method. 
For the credits in this last category, once more, the evaluation is restricted to emissions of specific substances for particular materials not taking into account the holistic view of the potential impacts and their causes.

Similarly to LEED, the AQUA certification system presents an methodology using the assessment by attributes for all its credits related to building components, as seen in Table 3.

The first credit, "Constructive choices for durability and adaptability of the building" considers the lifespan of the products, systems and processes according to their use in the building.

The evaluation item "Constructive choices for ease maintenance of the building" evaluates the choice of products of easy conservation and maintenance, whereas in "Choice of construction products in order to limit the social and environmental impacts of the construction" the evaluation of the construction materials is related to the emission of greenhouse gases, generation of waste, reuse and recycling of materials, use of renewable resources and depletion of natural resources. The last is one of the credits that most closely resembles the concepts of LCA in this certification, however without its holistic character.

The last credit of AQUA certification - "Choice of construction products in order to limit the impacts of construction to human health" - considers the available information on the product characteristics regarding the emissions of pollutants harmful to human health. The evaluation parameter in this credit slightly touches the typical Life Cycle Impact Assessment (LCIA) Human Health contributors, however it only considers harmful substances in the final product composition, regardless potential hardazous substances applied or emited during the other stages of products life cycle.

GBTool, unlike the certification systems previusly analized in this paper, has shown an advance in the credit "Primary energy embodied in materials", which evaluates such an issue by an inventory of energy inputs throughout the life cycle of the materials used in a building (Table 4). Although it is important to stress that this progress is still very incipient, since the use of a partial life cycle inventory (since it only computes the energy inputs and outputs) is an attributes evaluation with life cycle perspective, i.e., such a methodology does not evaluate the product holistically, either the potential impacts derived from such energy consumption.

Other credits in the GBTool Resource Consumption category ("use of salvaged materials from off-site sources", "recycled content of materials from off-site sources", "use of certified or equivalent wood products"), as shown in Table 4, evaluate the environmental performance of the building components using only the attributes perspective.

The evaluation item "Use of salvaged materials from off-site sources" measures the percentage of materials recovered from external sources in relation to the total weight of the materials used in the building. The credit "Recycled content of materials from off-site sources" considers the recycled content percentage of the total mass of used materials. The credit "Use of certified or equivalent wood products" assesses the percentage of the wooden systems composed of certificied materials.

Though the subjects issued by these credits are significantly important to building environmental assessment, such approaches assess them only punctually in order to achieve the minimum score, as already observed in the previously analyzed systems.

Still regarding the GBTool certification systems, the credits comprised by the "Loadings" category also use the attributes approach as evaluation methodology. It is the case of the credits regarding emissions of ozone- 
depleting substances, gases leading to acidification from building operations and avoidance of solid waste resulting from construction processes. These items evaluate the environmental performance of building components by accounting its emissions by building area or, in the case of solid waste, calculating the percentage of waste in relation to the mass of materials used in the construction.

Although such credits do mention some LCIA impact categories, only the emissions inventory is actually required and thus there is no characterization of the potential impacts of each substance considered.

The GBTool certification system still has one more credit regarding the "embodied emissions of materials, annualized over the life-cycle" which, despite its nomenclature, only considers the emissions from the production process of the analyzed material.

Finally, only the Green Globes certification system makes use of the Life Cycle Assessment as a tool to evaluate the environmental performance of building components. This rating system also comprises the credit "Minimum consumption of resources", which uses the attributes evaluation approach by considering the use of recycled, reused, locally sourced and low-maintenance materials and certified wood. However the main evaluation credit of this certification is "Low-impact materials and systems", which requires the application of a full LCA study to evaluate the potential environmental impacts of the construction materials used in the building.

It is important to observe that the Green Globes certification system uses only two credits for the assessment of environmental performance of building materials. This is probably due to the use of a full LCA study which derives by itself as much information as possible about the product concerned by analyzing holistically its potential environmental impacts.

\section{CONCLUSIONS}

This paper has shown that, among the four of the main and most employed building environmental certification rating systems currently in use, Green Globes is the only one which uses the Life Cycle Assessment methodology to evaluate building materials components. This methodological feature is probably a legacy from the BREEAM rating system, in which the Green Globes was originally based. The BREEAM certification requires the use of LCA for building materials assessment in its evaluation credits "Life cycle impacts" and "Hard landscaping and boundary protection".

The other systems observed in this paper use the attributes evaluation as assessment methodology.

The attibutes evaluation does not have a holistic coverage of the product life cycle and may lead to imperfect, incomplete and potentially misleading results and conclusions.

The LCA is a consistent and accurate quantitative environmental assessment methodology which should be used by such certification systems as a tool to evaluate the environmental performance of all the components of a building.

Among the main reasons for the limited use of LCA in the environmental certification systems of buildings there is its implementation complexity, as it demands considerable time and effort. The extent of the efforts employed in an LCA study makes its implementation hardly feasible in a certification process.

The LCA could mostly be employed in cases whose inventory databases are available to the building components analyzed. Even this possibility has 
shown very little feasible due to the scarcity of available data on the life cycle inventories of building materials.

Despite the higher effort required for the implementation of a comprehensive LCA study, the results are significantly more complete and expressive in comparison to the attributes evaluation methodology. Therefore, the use of a single evaluation credit which applies an full LCA is able to replace a much larger set of credits whose use attributes evaluatiom. Moreover it would provide more complete and consistent results once the LCA methodology analyses all possible environmental attributes of a product from a holistic point of view, considering all the possible interrelations between them.

Furthermore the massive development of LCA studies on building materials and the availability of their results in widely accessible databases would facilitate the use of such LCA data in the certification process.

\section{ACKNOWLEDGEMENTS}

The authors would like to acknowledge CAPES (Higher Education Personnel Improvement Coordination) and FINEP (Funding of Studies and Projects) for the financial support given to this research.

\section{REFERENCES}

ASSOCIAÇÃO BRASILEIRA DE NORMAS TÉCNICAS - ABNT. NBR ISO 14040: Gestão Ambiental - Avaliação do Ciclo de Vida: princípios e estrutura. Rio de Janeiro: ABNT, 2009.

BRIBIÁN, I. Z.; USÓN, A. A.; SCARPELLINI, $S$. Life cycle assessment in buildings: State-of-the-art and simplified LCA methodology as a complement for building certification. Building and Environment, Oxford, v. 44, p. 25102520, 2009. http://dx.doi.org/10.1016/j. buildenv.2009.05.001

BUENO, C. et al. Avaliação de Desempenho Ambiental de Edificações Habitacionais: Apresentação de Metodologia para Análise Comparativa de Sistemas de Certificação no Contexto Brasileiro. In: ENCONTRO LATINO-AMERICANO SOBRE EDIFICAÇÕES E COMUNIDADES SUSTENTÁVEIS - ELECS, 4., 2011, Vitória. Anais... Vitória, 2011. v. 1. p. 1-10.

BUILDING RESEARCH

ESTABILISHMENT - BRE. BREEAM New

Construction: Technical Manual. London: BRE, 2011.

\section{CERTIVÉA. Haute Qualité}

Environnementale - HQE: Assessment Scheme for the Environmental Performance of Buildings. Certivéa, June 2012.
CHEVALIER, J. L.; LE TENO, J. F. Requirements for an LCA-based model for the evaluation of the environmental quality of building products. Building and Environment, Oxford, v. 31, n. 5, p. 48791, 1996. http://dx.doi.org/10.1016/03601323(96)00016-9

COLE, R. J.; LARSSON, N. Green Building Challenge 2002: GBTool User Manual. Otawa: Green Building Challenge, 2002.

ERLANDSSON, M.; BORG, M. Generic LCA-methodology applicable for buildings, constructions and operation services - today practice and development needs. Building and Environment, Oxford, v. 38, p. 919-938, 2003. http:// dx.doi.org/10.1016/S0360-1323(03)000313

FUNDAÇÃO CARLOS ALBERTO VANZOLINI. Referencial Técnico de Certificação: edifícios do Setor de Serviços - Processo AQUA. GEAConstruction, 2007. Disponível em: <http://www.geaconstruction.com/ arquivos/HQE\%2OFCAV\%202007\%20 \%20Completo\%2015\%2010\%2007\%20 v21\%20sem\%20revisões\%20-rm2-ca.. pdf>. Acesso em: 11 set. 2008.

GUSTAVSSON, L.; JOELSSON, A. Life cycle primary energy analysis of residential buildings. Energy and Buildings, Lausanne, v. 42, n. 2, Feb 2010. 
HAAPIO, A.; VIITANIEMI, P. A critical review of building environmental assessment tools. Environmental Impact Assessment Review, New York, v. 28, p. 469-82, 2008. http://dx.doi. org/10.1016/j.eiar.2008.01.002

HANS, J. et al. French national service life information platform. In: INTERNATIONAL CONFERENCE ON DURABILITY OF BUILDING MATERIALS AND COMPONENTS, 11., 2008, Istanbul. Proceedings... Istanbul, 2008.

JOHN, V. M.; OLIVEIRA, D. P.; AGOPYAN, V. Critérios de sustentabilidade para seleção de materiais e componentes - uma perspectiva de sustentabilidade para países em desenvolvimento. Building and Environment, Oxford, 2006.

NIBEL, S. et al. Annex 31: energy related environmental impact of buildings, technical synthesis report. International Energy Agency, 2005. Disponível em: $<$ http://www.iisbe.org/annex31/ index. html $>$.

PATRICIO, R. M. R.; GOUVINHAS,

R. P. Avaliação de Desempenho Ambiental em Edificações: Diretrizes para o Desenvolvimento de uma nova metodologia adaptada à realidade do Nordeste. In: CONFERÊNCIA LATINOAMERICANA DE CONSTRUÇÃO SUSTENTÁVEL, 1.; ENCONTRO NACIONAL DE TECNOLOGIA DO AMBIENTE CONSTRUÍDO, 10., 2004, São Paulo. Anais... São Paulo, 2004.
SOARES, S. R.; SOUZA, D. M.; PEREIRA, S. W. Avaliação do ciclo de vida no contexto da construção civil. Porto Alegre: ANTAC, 2006. (Coletânea Habitare, v. 7 - Construção e Meio Ambiente).

SILVA, V. G. Uso de Materiais e Sustentabilidade. Sistemas Prediais, São Paulo, v. 1, p. 30-34, jul. 2007. Disponível em: <http://www.nteditorial.com.br/ revista/Materias/index.asp?RevistalD1= $7 \&$ Edicao $=22 \& i d=200 \&$ TopicolD $=318$. Acesso em: 10 ago. 2009.

SKOPEK, J.; BRYAN, H. Green Globes: and online assessment tool for benchmarking building performance. Canada, 2002

UNITED STATES GREEN BUILDING COUNCIL - USGBC. Leadership and Energy \& Environmental Design - LEED: Green Building Rating System. version 3. USGBC, Jan 2009.

VERBEECK, G.; HENS, H. Life cycle inventory of buildings: A contribution analysis. Building and Environment Oxford, v. 45, n. 4, Apr 2010. 